\title{
Personal e-Learning Environment of a Mathematics Teacher
}

\author{
Kateryna Vlasenko ${ }^{1}$, Olena Chumak ${ }^{2, *}$, Vitaliy Achkan ${ }^{3}$, Iryna Lovianova $^{4}$, Oksana Kondratyeva $^{5}$ \\ ${ }^{1}$ Department of Mathematics and Modeling, Donbas State Engineering Academy, Ukraine \\ ${ }^{2}$ Department of General Engineering, Donbas National Academy of Civil Engineering and Architecture, Ukraine \\ ${ }^{3}$ Department of Mathematics and Methods of Learning Mathematics, Berdyansk State Pedagogical University, Ukraine \\ ${ }^{4}$ Department of Mathematics and Methods of its Training, Kryvyi Rih State Pedagogical University, Ukraine \\ ${ }^{5}$ Department of Mathematics and Methods of Teaching Mathematics, Bohdan Khmelnytsky National University of Cherkasy, Ukraine
}

Received May 1, 2020; Revised June 12, 2020; Accepted June 15, 2020

Copyright $\odot 2020$ by authors, all rights reserved. Authors agree that this article remains permanently open access under the terms of the Creative Commons Attribution License 4.0 International License

\begin{abstract}
This paper is aimed at creating a model of a Personal e-Learning Environment (PLE) of a University Mathematics teacher. A special emphasis is put on the analysis of the approaches to understanding the notion Personal e-Learning Environment (PLE) and studies into creating a PLE model. The Deductive Content Analysis of the research papers and other academic sources in this article allowed defining the structure of the PLE model of University Mathematics teachers. The authors of the present paper see the bottom line of the modelling process as giving content to the PLE according to the types of teaching activities, which Mathematics teachers do to perform the Instructive, Cognitive, Designing, Planning, Social, Managerial roles. With the help of The Inductive Content Analysis Method the researchers in this paper analysed the data on ranking web-services. The data were taken from the web-resources and helped to select web 2.0 tools, which can be used to give content to the PLE. The conducted research made it possible to conclude that the idea to develop a PLE model of a teacher is based on such factors as the ranking of web-tools, IK competency of a teacher and his/her willingness to develop professionally. The authors of the present article assessed the answers of the academic staff at Ukrainian Universities concerning their level of awareness about using web-tools in teaching. The analysis of the results proved the insufficient level of such awareness and justified the relevance of designing an on-line course in order to support a Mathematics teacher in creating and using Personal e-Learning Environment.
\end{abstract}

\section{Keywords Personal e-Learning Environment,} IK-competencies of a University Maths Teacher, Types of Activities, Web-tools, A Personal e-Learning Environment Model

\section{Introduction}

\subsection{Problem Statement}

For the time being there are numerous Web-resources for searching, saving, classifying, analyzing, sharing and processing information. While making a choice, every person has an opportunity to design Personal Learning Environments (PLE) according to their line of work. University Maths teachers are not an exception, since their professional activity comprises not only teaching students, but also doing research, analysis and statistical processing of the information, doing calculations, publishing research papers, popular science materials, presenting reports and materials, communication and collaboration, etc. Added to that, to be comply with the needs and demands of students, teachers must constantly improve their skills in using new resources, but, according to a research by Bennett et al. [1], Perikos et al. [2], Yadav \& Patwardhan [3], Vlasenko et al. [4], teachers mostly are not familiar with social media and other useful resources of Web 2.0. All things considered, mastering new resources and designing own PLE calls forth timeliness of developing methods and ways to help and support Maths teachers.

\subsection{Analysis of Recent Research Papers and Publications}

Various definitions of Personal Learning Environments were offered by a number of scholars, such as Attwell [5], Drexler [6], Harmelen [7], Adell Segura \& Castañeda Quintero [8], Alharbi et al. [9], Kompen et al. [10], McLoughlin and Lee [11] and others. But still there is no universally accepted definition of the term. As Kompen et al. [10] state, there are two approaches to defining PLE. 
Following an educational approach, PLE is viewed as methodology or a concept [8]. Technically speaking, PLE is described as an object, a platform or an infrastructure [7].

The authors of this article will follow a definition, proposed by Kompen et al. [10], who consider PLE to be a set of web-technologies having different level of integration, which helps users manage the flows of information on education, knowledge creation and skills development.

Among studies on the methods for designing Personal Learning Environments, the ones focused on designing PLE for schoolers and students prevail. Their goal is e-learning, remote or non-formal learning. Thus, Kompen et al. [10] drafted general guidelines for implementation and usage of personal learning environment by students in a formal format in higher education (University level). Alharbi et al. [9] tried to give students an opportunity to design own technologies of PLE, such as blogs, web-sites and Web 2.0 services. The researchers offered a model for designing PLE, which covers both traditional formal (in Universities), and informal (private) academic learning. Drexler [6] describes K-12 student design of personal learning environments and puts forward suggestions for enhancing on-line self-education. Shaikh and Khoja [12] emphasize the necessity to study the role, which a teacher plays in the learning process. The researchers outline the competencies, necessary for teachers who help students plan or design Personal Learning Environments. Couros [13] holds the same opinion, and states that a teacher can provide on-line learning better, if he or she designed their own PLE model. The researcher himself designed such a model, taking into consideration all the information which he had received from secondary school teachers, who actively participated in on-line learning for professional development. Researchers support the concept of the model by Couros [13], which reckons for analysis of certain types of teachers' activities. All the recommendations of the researcher are taken into account, when designing a PLE model of a University Maths teacher and the authors of this paper build on the types of activities, which teachers do as well.

Such an approach, according to Perikos et al. [2] will help to identify the most suitable tools to create contents for PLE. Moreover, scholars firmly believe, that such research will contribute to developing educational on-line courses on how to use Web 2.0 tools. The authors of this study share the opinion that such courses are to provide University teachers with an opportunity to master skills and enhance their expertise, following the life-long learning concept.

Relevance and timeliness of the issue of designing PLE for Maths teachers was discussed during the International Conference on Sustainable Future: Environmental, Technological, Social and Economic Matters (ICSF 2020) [14], [15], the participants of which came to a conclusion about the necessity to develop and implement on-line support for Maths teachers in designing PLE.

The present article is aimed at identifying the types of activities of a University Maths teacher; selecting Web resources which can help make these activities more varied and can be used to provide content for PLE; designing PLE models of a University Maths teacher.

\section{Materials and Methods}

Applying deductive content analysis of research papers by Couros [13], Kadle [16], Quinn [17], Morrison [18], the authors of the present paper came to a conclusion about the necessity to structure PLE of University Maths teachers, based on the types of their activities. When singling out the types of such activity, the authors also took into consideration the survey results. The questionnaire which had 16 questions was devised with the help of an open on-line service and uploaded to the platform Higher school mathematics teacher [19]. 75 respondents, all of whom are Mathematics lecturers at Ukrainian technical universities, took part in the survey. $70 \%$ of them have over 15 years of working experience; $56.5 \%$ hold a position of an Assistant Professor, $30.4 \%$ are Professors. The questions were aimed at defining the level of the awareness of the academic staff about using web-resources for various types of teaching activity:

1. arranging the learning process;

2. searching for information;

3. doing research, analysis and statistical processing of the information;

4. doing the calculation;

5. publishing research papers;

6. publishing popular science materials;

7. designing presentations;

8. collaborating and communicating;

9. saving data.

One more goal of doing this survey was to identify how aware Ukrainian teachers are about using Web resources to carry out a definite type of activity. The analysis of the responses of Ukrainian University teachers will be presented in the findings of the survey. Added to that, with the help of the inductive content analysis method the authors of the present article analysed the data from web-resources, where ranking of Web-tools takes place according to how popular they are.

Thus, while selecting resources for organizing the teaching process, the authors of the present paper kept focus on on-line courses, that are ranked in the Top Tools for Learning 2019, which was compiled by Jane Hart based on the results of the 13th annual learning tools survey [20]. The most frequently used are Collections of online courses and resources (Coursera), EdX - Online courses from the world's best universities, Alison - Online courses from the world's top publishers, LinkedIn Learning (Lynda), Academic Earth - Online college courses from the world's 
top universities and others. But most of these resources are not translated into Ukrainian, which hampers the Ukrainian University teachers to use them.

Every country has its own preferable service of on-line search for the necessary information. According to the data provided by Statcounter [21], search engine Google is an absolute leader all over the world (approximately 90\%), others, such as Bing, Baidu, Yahoo, Yandex are used in less than $4 \%$ of cases. This data is presented by Project-Seo [22], which does the estimate of search engines that are the most popular among Ukrainian users.

Roik et al. [23] described the market of statistical packages for doing research, analysis and statistical processing of information. As the researchers emphasize, the programs for statistical analysis can be divided into three main groups by their functionality: universal packages, or general-purpose packages; professional packages; specialized packages. Identifying the best software for providing statistical analysis, Capterra [24] compares feedback from users and functions of the product, assigning the first places to MatLAB SPSS by IBM and XLSTAT by Addinsoft. Some of the most frequently used universal packages in Ukraine, such as Stadia, Statgraphics, SPSS, Statistica, MS Excel (MicroSoft Corp) are also on Capterra's list.

Describing the best software for doing calculations, Free Maths The Geek Page [25] draws attention to the ones that can be downloaded by users for free. When preparing a list of Mathematical software, the experts took into consideration the opinions of users about their advantages in terms of frequency of usage. The ones which come top of the list are Microsoft Mathematics, Math Editor, Maple, MathCAD, Mathematica (Wolfram Research, Inc), Cantor, KAlgebra, Mathomatic, Scilab, Maxima, Octave, FreeCAD, PythonCAD, QCAD, Varkon, Linuxcad, Varicad, Cycas, Tomcad, Thancad, Fandango, Lignumcad and others.

Since publishing popular science materials is the most widespread activity among the Internet users all around the world nowadays, YouTube comes first on the list of Top Tools for Personal \& Professional Learning [20] and is top of the list in Top Tools for Higher Education, TED Talks comes second, Pinterest holds the 22nd place. Instagram, according to the data by Top Tools for Personal \& Professional Learning holds the 32 nd place. Despite this fact, uploading video lessons, video lectures, tutorials on YouTube, TED Talks or running Mathematical pages on Instagram is not so popular among Ukrainian teachers.

Currently University teachers have to meet much higher professional requirements, which calls forth topicality of publishing articles and scientific papers. In this case web-sites with lists of professional publications of Ukraine which are indexed in Scopus and WoS, for instance Open Science in Ukraine [26], can be very useful. Moreover, a teacher must be registered in a worldwide database Scopus [27], to receive H-index Scopus, in data base Publons [28], to receive $\mathrm{H}$-index $\mathrm{Web}$ of Science, and have a personal identifier ORCID iD [29]. There are other data bases for scholars which allow them to track their publications getting cited by others, Google Scholar [30]. However, these resources make only a small part of what is offered by a blog Connected researcher [31], where one can find digital tools for supporting scientific research, which can be better presented through those tools.

Nowadays a vast range of tools for making presentations of reports and other materials is in place. According to Jensen [32], who enlists The Ultimate List of FREE Presentation Tools, the top four software tools for streaming presentations are PowerPoint, Keynote, Google Slides and Prezi. Envato Tuts [33] describes alternatives to widely used PowerPoint and suggests using other tools for processing various documents and designing presentations, Only Office Online Presentation Editor, Zoho Show, PowToon, Slide Rocket, Open Office.org Impress, Quick Slide Show, MySlideShow being among them.

For collaboration, communication, generating ideas, taking notes Emerging EdTech [34] offers teachers tools, such as Twiddla, Google Drive, Evernote, OneNote, Blackboard Collaborate, PB Works, Popplet. These tools can provide teachers with a wide array of functionality, for instance communication and joint editing of documents.

As for Ukrainian teachers, they opt for Facebook, Twitter, LinkedIn, Yammer, e-mail, Skype. A blog e-Learning Industry [35] identifies Google Drive, Podio, TitanPad, Show Document, Thinkbinder among the best free tools for joint collaboration of teachers.

All the types of teachers' activities, described above are impossible without efficient arrangement of saving data, so developers of Big Data Made Simple [36] suggest using such tools as Microsoft HDInsight, NoSQL, Big data in EXCEL, Presto, Skydrive, Google Drive, Dropbox, OneDrive.

Having put a thoughtful consideration into all the recommendations of the resources that suggest ranking Web-tools according to how popular and sought for they are and being aware, that designing PLE is a personal matter of each and every teacher, the authors of this article developed a PLE model of University Maths teachers (Figure 1). When designing the model, they took account of the answers by Ukrainian University Maths teachers. See the analysis below. 


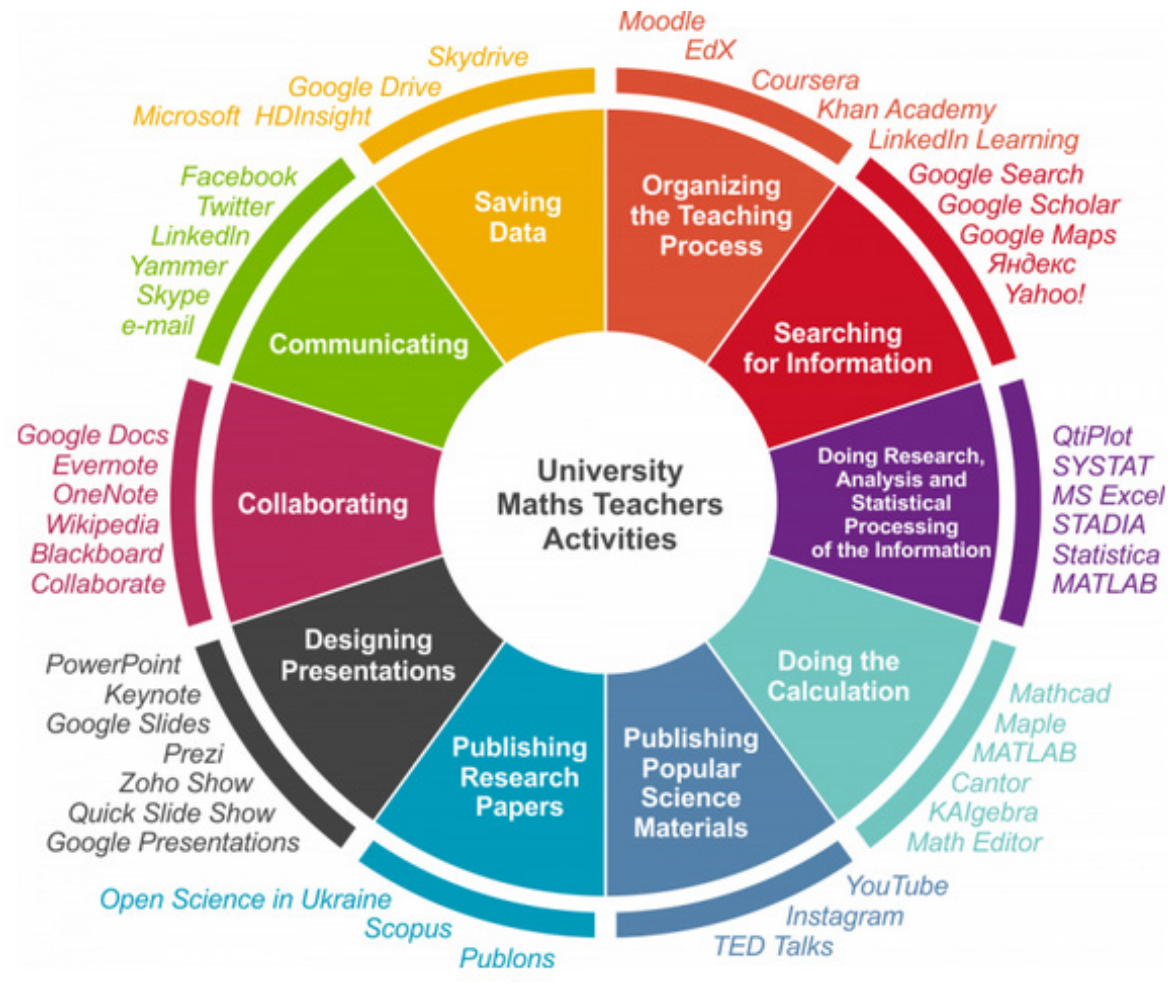

Figure 1. PLE model of University Maths teachers

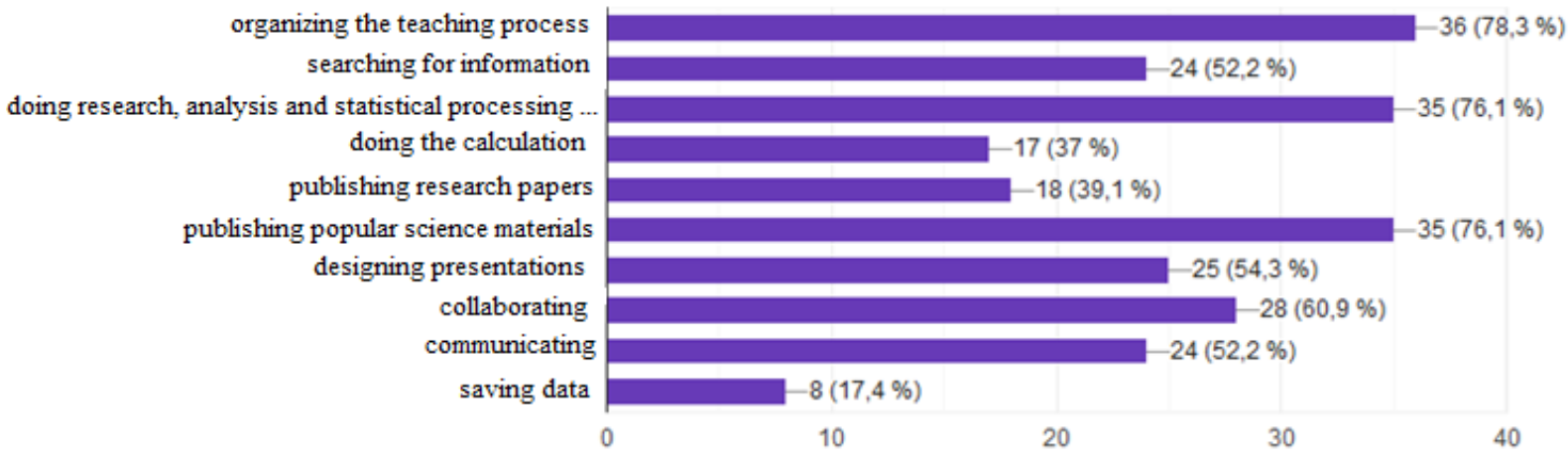

Figure 2. Allocation of types of teaching activities by priority

\section{Results}

Designing a PLE model of a University Maths teacher researchers in the present study took into consideration the fact that the selection of Web-tools depends on IK-competencies of teachers and their willingness and readiness to improve own qualifications. Answers to the questionnaire helped the authors get the big picture. It is worth mentioning that $100 \%$ of the respondents consider further learning (upon obtaining an advanced degree) to be a must, and getting support in designing PLE is of utmost importance.

$78.3 \%$ of the respondents consider organizing the teaching process to be the most important activity for a University teacher. Doing research, analysis and statistical processing of the information (76.1\%) and publishing research papers $(76.1 \%)$ take the second place.
Collaboration is the third on the list $(60.2 \%)$, communication - the forth $(52.2 \%)$. The answers are presented in Figure 2.

Moodle became a frequently used tool for devising teaching activities for $80.4 \%$ Ukrainian teachers, while only $23.9 \%$ of the respondents indicated that they are familiar with Coursera courses. $87.5 \%$ of the teachers mentioned using various software among the tools for doing research, analysis and statistical processing of information, but $21.7 \%$ of the respondents answered that they use predominantly on-line calculators.

$56.5 \%$ of the respondents do not use any resources for having their popular science materials published, thus losing a significant amount of influence on the on-line community. Thus, a conclusion can be made that Ukrainian teachers are still unaccustomed to such activity, so it makes sound sense to support it in form of on-line courses. 
$100 \%$ of the teachers-respondents carry out considerable research activities. $95.7 \%$ of the respondents have their materials published in professional journals, and $80.4 \%$ - in publications that are indexed in Scopus and WoS (Figure 3).

Among the tools for designing presentations of reports and materials, $80 \%$ of teachers opt for PowerPoint, only $31.1 \%$ of the respondents look for alternatives to it (Figure 4).
The survey shows that University Maths teachers are not fully aware of the sphere of PLE tools usage for different types of activities. The teachers mostly use the same tools over years, which is proved by this number $-39.1 \%$ of the respondents agreed to take the PIAAC test [37], which measures knowledge of adults in one of the key competencies - processing information, namely - in using their skills at home, at work, in the community (Figure 5).

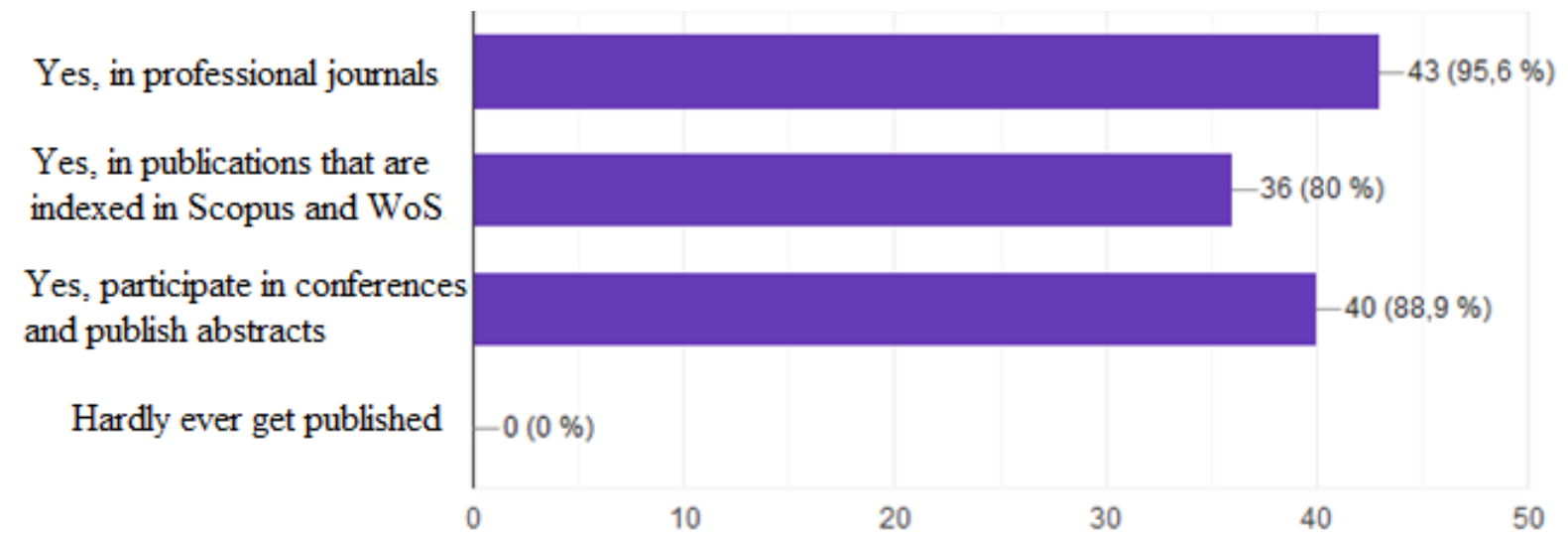

Figure 3. Allocation of teachers according to their participation in research activities

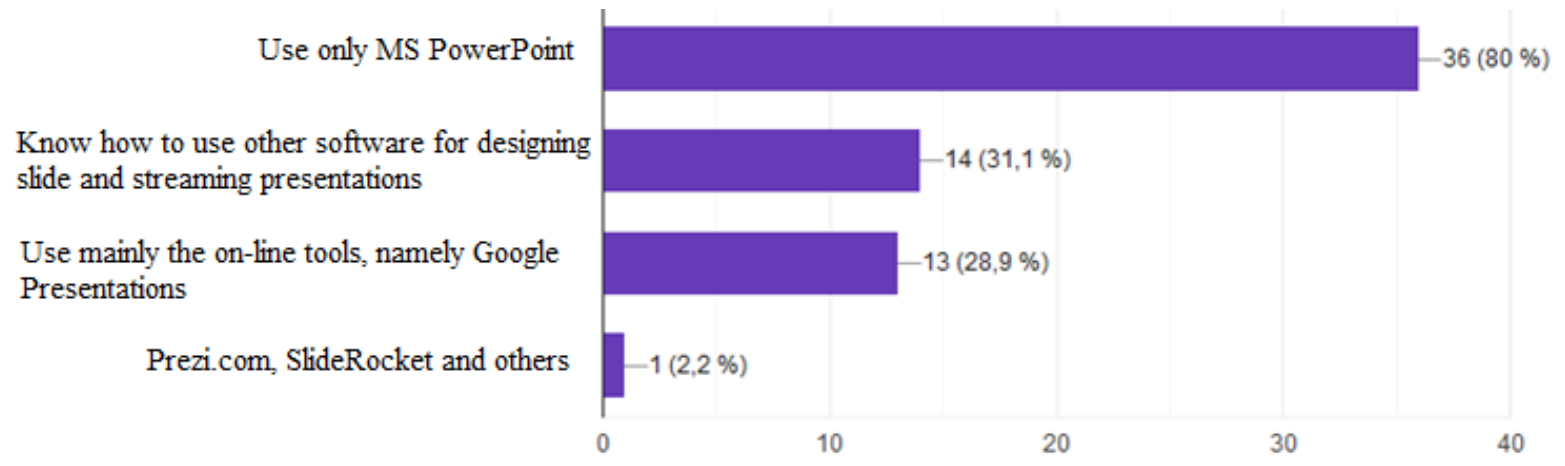

Figure 4. Allocation of teachers' opinions according to the choice of tools for designing presentations

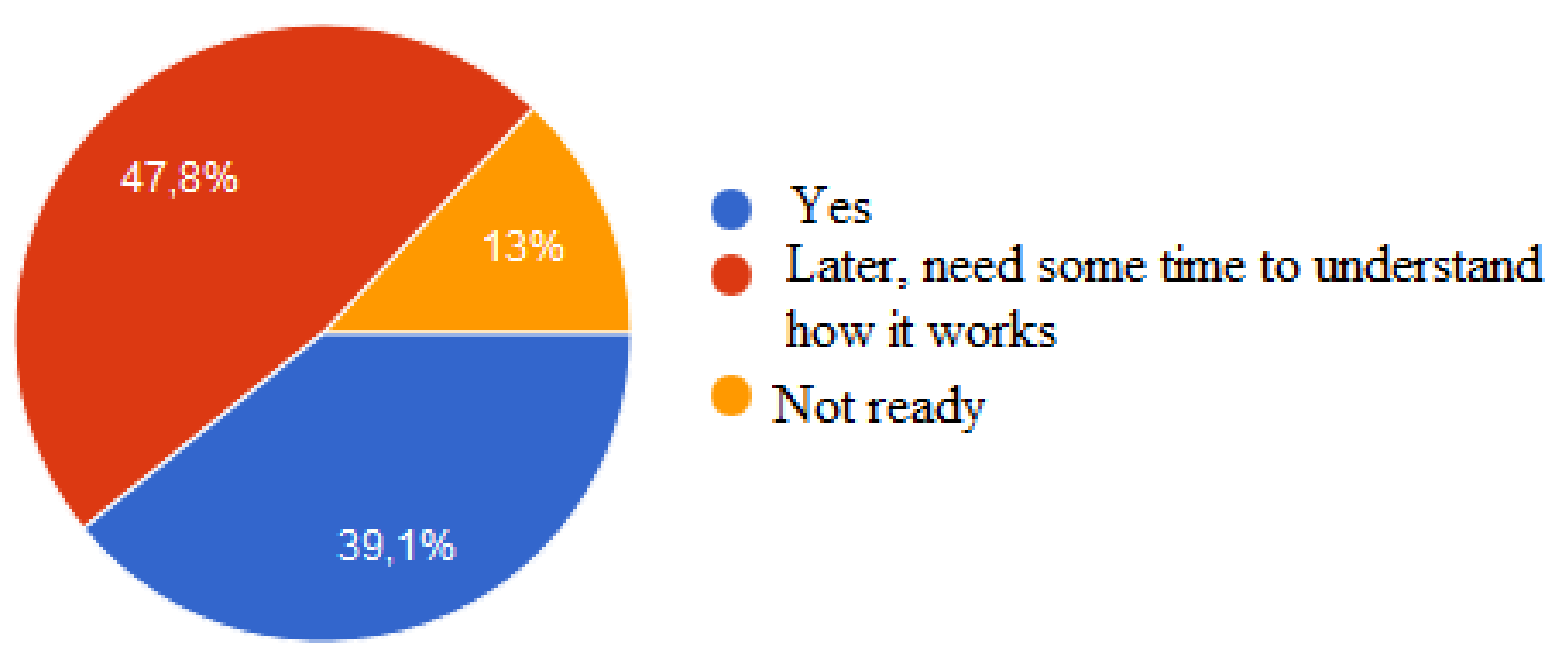

Figure 5. Allocation of teachers according to their readiness to take the PIAAC test 


\section{Discussion}

The idea about the relevance of creating a PLE model of a University Mathematics teacher found evidence in numerous research papers. Thus, according to Kompen et al. [10], currently both students and teachers are overloaded by the number of applications and Web 2.0 tools. The authors emphasize the necessity to develop a certain method for managing those applications through structuring the tools by digital identity. Trying to give the students an opportunity to develop their own PLE, Alharbi et al. [9] studied the development of blogs, web-sites and Web 2.0 services. The researchers also found that students had spent most of their time studying how to use the tools, necessary for their PLE. That is why the authors offered a certain model for developing PLE, which pursues two main goals: lifelong access and learner-centric study, covering both traditional formal and informal academic learning. The importance of creating a PLE through developing its model is proved by Malamed [38], who admits that such a model in place makes the process more methodical and gives a certain direction for further improvement.

The authors of the present paper agree with the conclusions by Bartolomé and Cebrian-de-la-Serna [39], who state that Personal Learning Environment varies for each person and must fully meet a person's needs and professional activities. Identifying the activities of University Maths teachers, researchers in this study also factor in the opinions of Shaikh and Khoja [12] and Vlasenko et al. [4], who believe that professional activity of a teacher is so various, as it comprises performing a lot of roles, for instance Instructive Role, Cognitive Role, Designing Role, Planning Role, Social Role, Managerial Role. Thus, a PLE model was devised, where a University Mathematics teacher plays a major role. In other words, a Mathematics teacher became a starting point for connectivity, for creating an external network, which helps a teacher to stay updated. Ranking web 2.0 services and their allocation according to the types of teaching activities, ensures the development of a beneficial personal environment that enables teachers to use various learning strategies and technologies when training students, and also to develop professionally. On the one hand, this set of tools can be edited by a teacher. On the other hand, the teacher cannot totally control this process, because of:

- a significant increase in using the Internet;

- redistribution of the roles between a student and a teacher, as a teacher, trying to live up to the students' expectations, starts learning from the latter;

- a student's engagement into creating, spreading, improving the learning content;

- expanding the audience that assesses and consumes the educational product globally.

Such prospects can dramatically change the paradigm of the learning process and mathematical education. Introducing web 3.0 resources into teaching Mathematics can play a major role in this process. The changes will impact upgrading the PLE model of both, a teacher and a student. There is likelihood that the model is going to improve in order to take into consideration personal needs and preferences of the stakeholders of the educational process. There is also an assumption, that such a clear delineation of the types of teaching activity will become impossible, as arranging the learning process, searching for information, doing the calculation, designing presentations, collaborating, communicating, saving data will blend. When arranging the learning process, Mathematics teachers have to change the objectives of their activity: to switch from imparting knowledge to assisting students in obtaining this knowledge; to become a counsellor on creating collaborative knowledge. A teacher will be focused on searching, editing and creating content. Searching information, and doing calculations will be done by students and teachers collaboratively. Making presentations will also upgrade to a new level: those will be on-line presentations and videos, on-line games that can be both, a means of learning and its outcome. Collaborating and communicating will be done non-stop with colleagues, as well as with students, but a border line in communication is going to blur, since anybody can communicate with the whole world at the same time via the Internet. There is ground to believe, that education 3.0 will provide new opportunities in terms of visualizing and modelling, creating programs for future research and educational scenarios. A student is going to become the centre of the learning process and a teacher will be a guide, a mentor, one more resource for obtaining knowledge. The question is, whether a Mathematics teacher is ready for such challenges.

Analyzing the results of a research by Bennett et al. [1], Perikos et al. [2], Yadav and Patwardhan [3], as well as responses of Ukrainian University Maths teachers, the authors of this paper come to a conclusion about deficient level of awareness of Ukrainian University Maths teachers about Web 2.0 tools usage.

Looking for a solution to this problem, Perikos et al. [2], Kauffman [40], Vlasenko et al. [42] proposed developing on-line courses for non-formal education of teachers. The idea of developing on-line courses aligns with the conclusions by Lovianova et al. [41], who researched forming IK-competency of students while teaching Mathematics-related subjects. The authors of this article believe that implementing such courses will ensure improving qualifications and boosting expertise of University Maths teachers. So, in future the authors offer to launch an on-line course "Personal e-Learning Environment of the Maths Teacher" [43] on the platform "Higher School Mathematics Teacher" [19].

\section{Conclusions}

The analysis of the resources and research papers 
supported the assumption, made by the authors of the present study concerning the necessity to use a wide range of Web 2.0 tools for carrying out various types of activities by teachers and students. Relevance and timeliness of designing a PLE model of a University Maths teacher result from specificities of professional activities of a Maths teacher, as well as from the necessity to constantly improve their ability to use new resources.

Using deductive content analysis alongside with taking into consideration the results of the survey, it was conducted among the Ukrainian teachers, which made it possible to identify the types of activities of a University Maths teacher. With the help of the inductive content analysis method, the authors of the present paper processed the data on ranking Web-tools by the demand, popularity, and prevalence. The respondents' answers to the questions in the survey and identifying awareness of Ukrainian teachers about the usage of Web resources for each type of activity became determining in designing a PLE model. While developing a PLE model of University Maths teachers, the authors factored in the rating of existing Web-tools and IK-competencies of teachers, as well as their readiness to improve own qualifications.

The analysis of the survey findings shows that teachers demonstrated lack of confidence in using cutting-edge resources to support their professional activity, since only $39.1 \%$ of the respondents agreed to take a PIAAC test (the Programme for the International Assessment of Adult Competencies, 2019). The survey findings also refer to the fact that University Maths teachers have insufficient level of awareness about Web 2.0 tools usage.

The authors of the present study are concerned that the solution to this problem lies in developing an on-line course for University Maths teachers in order to show them advantages of using personal e-learning environment and methods for designing thereof. The course can also be used by Master students majoring in Mathematics and all those who are interested in designing personal e-learning environment. Developing such a course is to become the main development vector for further research.

\section{Acknowledgments}

The authors of the present paper are grateful to all the participants of the surveys and active forum users.

\section{REFERENCES}

[1] S. Bennett et al. Implementing Web 2.0 technologies in higher education: A collective case study, Computers \& Education, 59(2), 524-534, 2012. doi.org/10.1016/j.comped u.2011.12.022

[2] I. Perikos, et al. Assisting tutors to utilize web 2.0 tools in education, International Conference e-Learning. 121-128, 2015. Online available from:https://pdfs.semanticscholar.or g/5d28/d66574236671b658a413f510b22f90d3f37a.pdf

[3] A. Yadav and A. Patwardhan. Use and impact of Web 2.0. tools in higher education: A literature review. Academic libraries in electronic environment, In: Parmar, S., Siwach, F, Intellectual Foundation, India, 218-246, 2016.

[4] K. Vlasenko, O. Chumak, I. Sitak, I. Lovianova, O. Kondratyeva. Training of mathematical disciplines teachers for higher educational institutions as a contemporary problem, Universal Journal of Educational Research, 7(9), 1892-1900, 2019. doi: 10.13189/ujer.2019.070907

[5] G. Attwell. Personal Learning Environments-the future of eLearning? eLearning Papers, vol. 2, 1-7, 2007. Online available from: http://citeseerx.ist.psu.edu/viewdoc/downlo ad?doi=10.1.1.97.3011\&rep=rep1\&type $=$ pdf

[6] W. Drexler. The networked student model for construction of personal learning environments: Balancing teacher control and student autonomy, Australasian Journal of Educational Technology, 26(3), 369-385, 2010.

[7] M. Harmelen. Personal Learning Environments. Proceedings of the 6th IEEE International Conference on Advanced Learning Technologies, ICALT 2006, Kerkrade, The Netherlands. doi: 10.1109/ICALT.2006.1652565

[8] J. Adell Segura \& L. Castañeda Quintero. Los Entornos Personales de Aprendizaje (PLEs): una nueva manera de entender el aprendizaje. En Roig Vila, R. \& Fiorucci, M. (Eds.) Claves para la investigación en innovación y calidad educativas. La integración de las Tecnologías de la Información y la Comunicación y la Interculturalidad en las aulas. Stumenti di ricerca per l'innovaziones e la qualità in ámbito educativo. La Tecnologie dell'informazione e della Comunicaziones e l'interculturalità nella scuola. Alcoy: Marfil - Roma TRE Universita degli studi, 2010.

[9] M. T. Alharbi et al. (2013). Personal Learning Environment, International Journal for e-Learning Security (IJeLS), Vol. 3, Issue 1, 280-288, 2013. doi:10.20533/ijels.2046.4568.2013. 0036

[10] R.T. Kompen, et al. (2019) 'Personal learning Environments based on Web 2.0 services in higher education', Telematics and Informatics, Vol. 38, pp. 194-206. doi:10.1016/j.tele.2018.10.003

[11] C. McLoughlin and M. J. W. Lee. Personalised and self-regulated learning in the Web 2.0 era: International exemplars of innovative pedagogy using social software, Australasian Journal of Educational Technology, 26(1), $28-43,2010$

[12] Z. A. Shaikh and S. Khoja. Role of teacher in personal learning environments, Digital Education Review, 21(2), 23-32, 2012.

[13] A. Couros. Examining the open movement: Possibilities and implications for education. PhD. University of Regina, 2006. Online available from: https://pdfs.semanticscholar.org/e29 6/d847df0d46d0e40993c7002c9e2a328cb28f.pdf

[14] K. Vlasenko, O. Chumak, I. Lovianova, D. Kovalenko, N. Volkova. Methodical requirements for training materials of on-line courses on the platform "Higher school mathematics 
teacher". The International Conference on Sustainable Futures: Environmental, Technological, Social and Economic Matters (ICSF 2020) E3S Web Conf., Vol. 166, 2020. doi:10.1051/e3sconf/202016610011

[15] K. Vlasenko, S. Volkov, I. Sitak, I. Lovianova and D. Bobyliev. Usability analysis of on-line educational courses on the platform "Higher school mathematics teacher". The International Conference on Sustainable Futures: Environmental, Technological, Social and Economic Matters (ICSF 2020) E3S Web Conf., Vol. 166, 2020. doi:10.1051/e3sconf/202016610012

[16] A. Kadle. Elements for Constructing Social Learning Environments. UPSIDE Learning Blog, 2010. Online available from: https://www.upsidelearning.com/blog/index .php/2010/03/10/elements-for-constructing-social-learningenvironments/

[17] C. Quinn. The Performance Environment. Learnlets, 2009. Online available from:https://blog.learnlets.com/2009/08/th e-performance-environment/

[18] D. Morrison. How to create a personal learning environment to stay relevant in 2013, Online Learning Insights, 2013. Online available from: https://onlinelearninginsights.wordp ress.com/2013/01/05/how-to-create-a-personal-learning-env ironment-to-stay-relevant-in-2013/

[19] Higher School Mathematics Teacher, 2019. Online available from: http://formathematics.com/

[20] Top Tools for Learning 2019. Online available from: http://c4lpt.co.uk/directory-of-learning-performance-tools/c ollections-of-online-courses-and-resources/

[21] Statcounter Globalstats, 2020. Online available from: https://gs.statcounter.com/search-engine-market-share

[22] Project-Seo. Search Engine Ranking 2019 - 2020. Online available from: https://project-seo.net/uk/blog-uk/rejtyng-p oshukovyh-system-2018-2019/

[23] M. Roik et al. Review of software for statistical data analysis, An efficient economy, № 7, 2017. Online available from: http://www.economy.nayka.com.ua/?op=1\&z=5676 [in Ukr.]

[24] Capterra. Statistical Analysis Software, 2019. Online available from: https://www.capterra.com/statistical-analysi s-software/

[25] Free Maths The Geek Page. Top 30 Best Free Math software you can use, 2019. Online available from: https://thegeekpage.com/best-free-math-softwares/

[26] Open Science in Ukraine, 2020. Online available from: https://openscience.in.ua/

[27] Scopus Preview, 2020. Online available from: https://www.scopus.com/home.uri

[28] Publons, 2020. Online available from: https://publons.com/account/login/?next=/dashboard/summ ary/

[29] ORCID. Connecting research and researchers, 2020. Online available from: https://orcid.org
[30] Google scholar, 2020. Online available from: https://scholar.google.com/

[31] Connected researchers. Digital tools for researchers, 2019 Online available from:http://connectedresearchers.com/onli ne-tools-for-researchers/

[32] G. Jensen. The Ultimate List of FREE Presentation Tools INSIGHTS: The Guthrie-Jensen Blog, 2019. Online available from:https://guthriejensen.com/blog/free-presenta tion-tools/

[33] Envato Tuts. Over 20 Best Presentation Making Software Alternatives to PowerPoint (2019), 2019. Online available from:

https://business.tutsplus.com/articles/best-presentation-soft ware-alternatives-to-powerpoint--cms-28697

[34] EmergingEdTech. 20 Fun Free Tools for Interactive Classroom Collaboration, 2014. Online available from: https://www.emergingedtech.com/2014/05/20-excellent-fre e-tools-for-interactive-collaboration-experiences-in-the-clas sroom/.

[35] eLearning Industry. The 5 Best Free Collaboration Tools for Teachers, 2013. Online available from: https://elearningindustry.com/the-5-best-free-collaborationtools-for-teachers

[36] Big Data Made Simple. Top big data tools used to store and analyse data, 2014. Online available from: https://bigdata-madesimple.com/top-big-data-tools-used-tostore-and-analyse-data/.

[37] OECD Skills Surveys. The Programme for the International Assessment of Adult Competencies (PIAAC), 2019. Online available from: http://www.oecd.org/skills/piaac/

[38] C. Malamed. Models for designing your personal learning environment, The e-Learning Coach, 2019. Online available from:

http://theelearningcoach.com/elearning2-0/designing-perso nal-learning-environment/

[39] A. Bartolomé \& M. Cebrian-de-la-Serna. Personal Learning Environments: A study among Higher Education students' designs, International Journal of Education and Development using Information and Communication Technology (IJEDICT), Vol. 13, Issue 2, 21-41, 2017. Online available from: https://files.eric.ed.gov/fulltext/EJ11 53337.pdf

[40] H. Kauffman. A review of predictive factors of student success in and satisfaction with online learning, Research in Learning Technology, Vol. 23, 2015. doi:10.3402/rlt.v23.26507

[41] I. Lovyanova, K. Vlasenko, A. Krasnoschok, D. Dmytriiev, R. Shponka. Modeling of ICT competence formation of would-be mathematics teacher, Information Technologies and Learning Tools, 74(6), 2019. Online available from: https://journal.iitta.gov.ua/index.php/itlt/article/view/2421

[42] K. Vlasenko, O. Chumak, I. Sitak, T. Kalashnykova, V. Achkan. CLIL Method to increase students' motivation in studying mathematics at higher technical school. Universal Journal of Educational Research, Vol. 8, No. 2, 362-370, 2020. Online available from: DOI: 10.13189/ujer.2020.080205 
[43] Personal e-Learning Environment of the Maths Teacher, 2020.

Online available

http://formathematics.com/courses/imt/personal-e-learningenvironment-of-the-maths-teacher/ 